\title{
Glacioclimatological features in the Tanggula mountains, China
}

\author{
Ding YongJian, Li Zhongein, LiU ShiYin ANd Yu XinZHi \\ Lanzhou Institute of Glaciology and Geocryology, Academia Sinica, Lanzhou 730000, China
}

\begin{abstract}
Air temperature and precipitation data have been obtained from the Geladandong region at the headwaters of the Yangtze River. At the equilibrium line altitude of the glaciers, mean annual and summer air temperatures are -10 to $-12.0^{\circ} \mathrm{C}$ and 1.0 to $-1.0^{\circ} \mathrm{C}$, respectively. Accumulation on the glaciers on the south side of the Tanggula mountains depends mainly on water vapour transported from the south and southeast. The moisture source for the glaciers on the north side is from the east. Precipitation increases with altitude in the glaciated areas. An estimated annual accumulation in the firn areas is about 400 to $600 \mathrm{~mm}$ of water equivalent. The Geladandon region has a cold, dry climate and the glaciers in the region can be classified as continental. The present climatic conditions result in a negative mass budget for most glaciers.
\end{abstract}

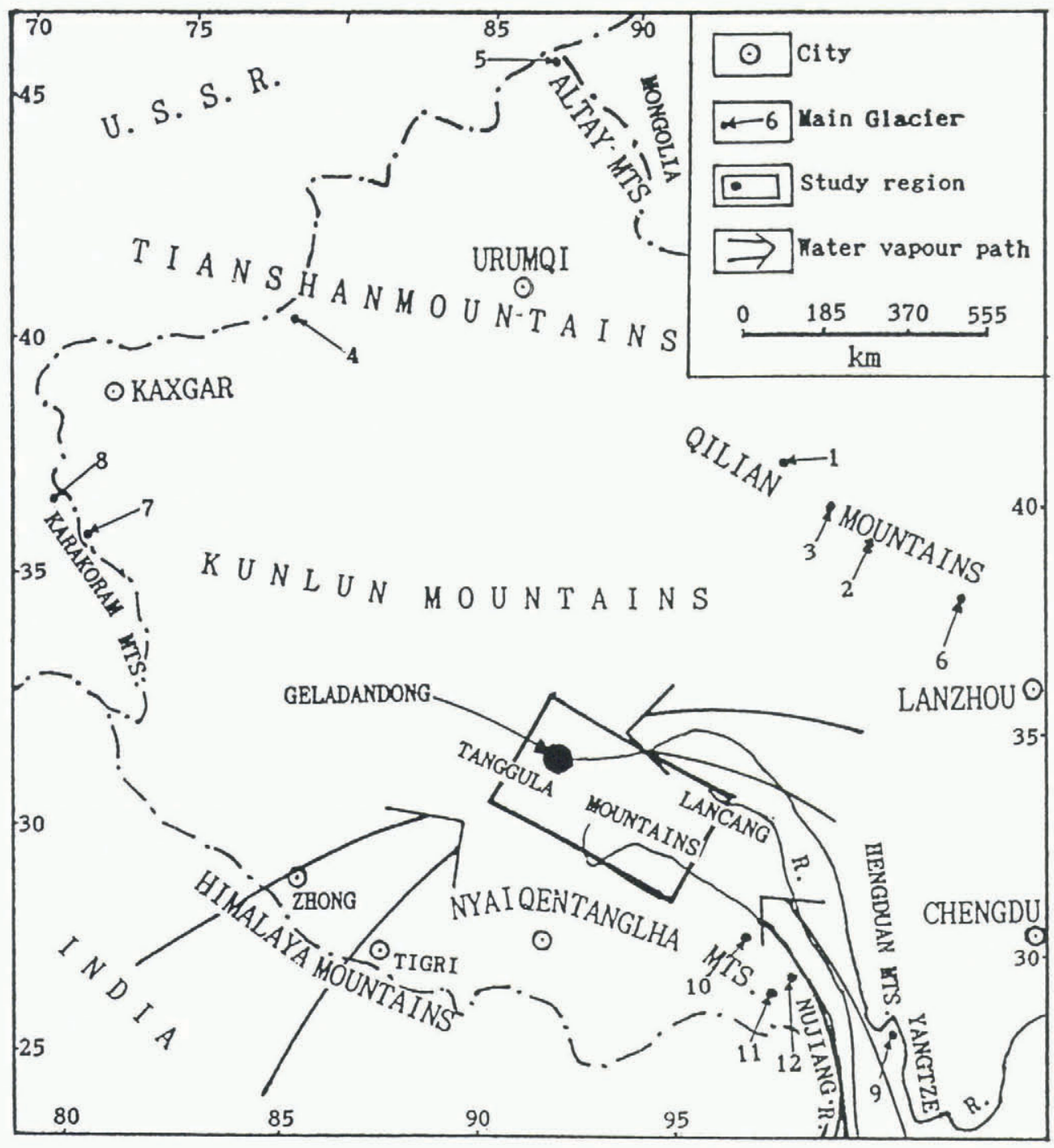

Fig. 1. Location of the research region. Numbers 1-12 also refer to Table 4. 


\section{INTRODUCTION}

The Yangtze River rises in the highest part of the Tanggula mountains in the vicinity of Geladandong mountain (Fig. 1). The region contains the principal concentration of glaciers in the interior of QinghaiXizhang Plateau. Zhang (1981) discussed the distribution and morphological features of the present glaciers and the palaeoglaciological conditions in this region. Up to now, however, there has been little information about the climatic conditions controlling the glacierization and its potential changes. This paper provides an analysis of climate data in relation to the present state of the glaciers.

\section{AIR TEMPERATURE IN THE GLACIER AREAS}

Direct measurements of air temperature in the glaciated areas have not been made. Air temperature was calculated by interpolation, based on data from meteorological stations around the glacierized areas. Three factors, altitude, longitude and latitude, were taken into consideration. In addition, a local factor must be included when air temperature over glaciers is estimated. The following method was used. First, the vertical air temperature gradient (VTG) was calculated on both sides of the Tanggula mountains, based on radiosonde measurements at meteorological stations (Table 1). The mean summer (June-August) VTG is about $0.6^{\circ} \mathrm{C}$ $100 \mathrm{~m}^{-1}$. The mean annual VTG is between 0.47 and

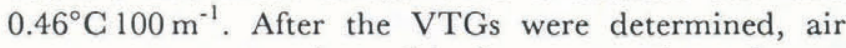
temperatures at various altitudes were estimated over every surface and radiosonde station around the glacierized areas. Figure 2 shows the air temperatures at $4500 \mathrm{~m}$ a.s.l., estimated using the VTG. Smooth isotherms, consistent with the stations, were drawn to represent the geographical variation of mean summer and mean annual air temperature. Both mean summer and mean annual air temperature tend to decrease from the southeast toward the northwest.

The altitude of glaciers is generally above $4500 \mathrm{~m}$ a.s.l., but air temperature at any altitude on a glacier surface can be estimated from Figure 2, using the VTGs. In an alpine region there may be local variations that are
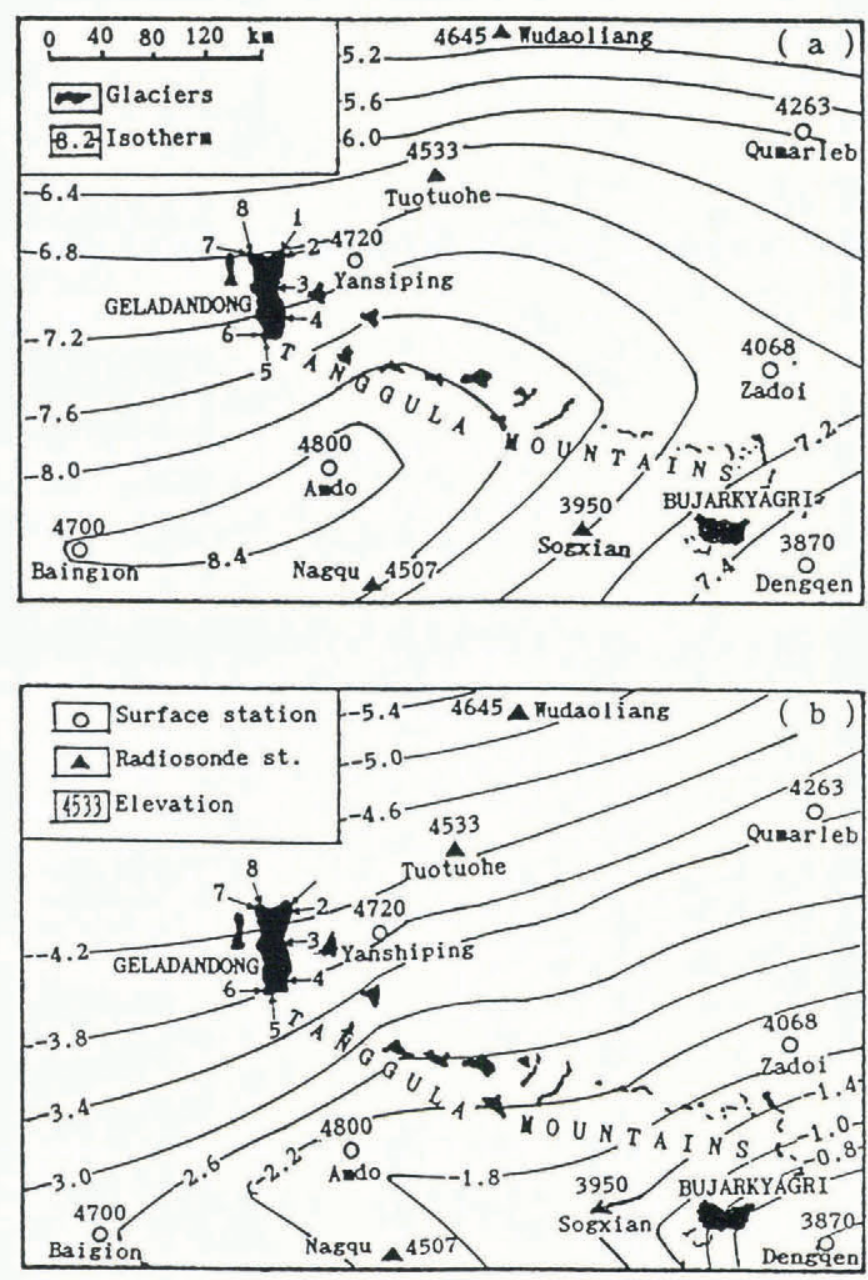

Fig. 2. Temperature distribution at $4500 \mathrm{~m}$ a.s.l. in ${ }^{\circ} \mathrm{C}$ : (a) mean summer air temperature (b) mean annual air temperature. Numbers 1-8 also refer to Table 2.

difficult to predict. However, a drop in air temperature is expected over a glacier which can be estimated from the size of the glacier, using empirical formulae (Kotlyakov and Krenke, 1982; Bai, 1989). Air temperatures above some of the largest glaciers of the Geladandong area, estimated by these means, are given in Table 2. The results indicate that air temperature is low in the

Table 1. Vertical temperature gradients in ${ }^{\circ} \mathrm{C} 100 \mathrm{~m}^{-1}$ from ground to $500 \mathrm{mbar}$ on the south and north sides of the Tanggula mountains (1965-80)

Jan Feb Mar Apr May fune fuly Aug Sept Oct Nov Dec Mean

The south side (Tuotuohe Station)

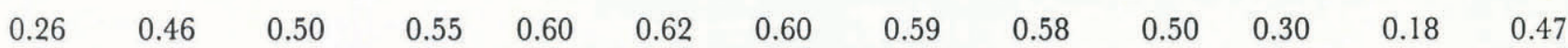

The north side (Nagqu Station)

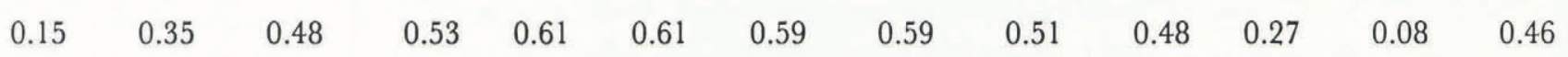


Geladandong region. Mean annual air temperature at the ELA is between -12.0 and $-10.0^{\circ} \mathrm{C}$ and mean summer air temperature is between -1.0 and $1.0^{\circ} \mathrm{C}$.

Air temperatures in other glacier systems of the Tanggula mountains have also been calculated using this method (Table 3). The mean terminal altitudes in the Geladandong, mid-Tanggula and Bujarkyagri areas are 5330, 5250 and $4700 \mathrm{~m}$ a.s.l. and the mean ELAs 5750, 5500 and $5350 \mathrm{~m}$ a.s.l., respectively. Air temperatures at the sites of these glaciers decrease northwestward both because of an increase in altitude of the glaciers in that direction and because of the regional trend of air temperature (Fig. 2). The especially low air temperatures in the glacierized area of Geladandong occur because of the location of this area at the northwest end of the range.
In comparison with air temperatures in various other glacier systems of China (Table 4), air temperatures in the Geladandong area are similar to those in areas of polar-continental glaciers. This indicates that the climate in the glacierized area of the Geladandong is cold and dry.

\section{SOURCES OF WATER VAPOUR}

Its interior location on the plateau causes the Geladandong area to be very dry. Precipitation in the Tanggula mountains is affected by the plateau summer monsoon $(\mathrm{Li}$ and others, 1986). Water vapour can reach the south side of the Tanggula mountains by two paths. One is the south and southwest path, through which water vapour moves

Table 2. Air temperature in ${ }^{\circ} \mathrm{C}$ in the Geladandong area (1960-80)

\begin{tabular}{|c|c|c|c|c|c|c|c|c|}
\hline \multirow[t]{2}{*}{ No. } & \multirow[t]{2}{*}{ Name of glacier } & Length & $E L A$ & $T A G$ & $T_{\text {so }}$ & $T_{\mathrm{ao}}$ & $T_{\mathrm{st}}$ & \multirow[t]{2}{*}{$T_{\mathrm{al}}$} \\
\hline & & $\mathrm{km}$ & $\mathrm{m}$ & $\mathrm{m}$ & & & & \\
\hline 1 & Kangnuqangma & 6.2 & 5655 & 5200 & 0.1 & -10.5 & 2.8 & -7.3 \\
\hline 2 & Gairi & 5.2 & 5826 & 5360 & -0.9 & -11.2 & 1.8 & -8.0 \\
\hline 3 & Kangkyagquba & 10.8 & 5820 & 5300 & -0.9 & -12.2 & 2.2 & -7.8 \\
\hline 4 & Jarhoangqu No. 10 & 9.9 & 5740 & 5340 & -0.4 & -10.8 & 2.0 & -7.9 \\
\hline 5 & N. Gyanggaindiuru & 10.3 & 5820 & 5400 & -0.9 & -11.4 & 1.6 & -8.3 \\
\hline 6 & S. Gyanggaindiuru & 12.8 & 5820 & 5395 & -0.9 & -1.4 & 1.6 & -8.3 \\
\hline 7 & Qiemeinsu No. 1 & 5.9 & 5540 & 5260 & 0.8 & -10.0 & 2.4 & -7.8 \\
\hline 8 & Qiemeinsu No. 6 & 9.2 & 5630 & 5390 & 0.4 & -10.5 & 1.7 & -8.4 \\
\hline
\end{tabular}

No. 1-8 see Figure 2. ELA, equilibrium line altitude; TAG, terminal altitude of glacier; $T_{\text {so }}$, mean summer air temperature at ELA; $T_{\text {ao }}$, mean annual air temperature at ELA; $T_{\text {st }}$, mean summer air temperature at TAG; $T_{\text {at }}$, mean annual air temperature at TAG.

Table 3. Mean monthly air temperature, in ${ }^{\circ} \mathrm{C}$, at mean ELA and mean terminal altitude (TAG) in various glacier systems of the Tanggula mountains (1960-80)*

\begin{tabular}{|c|c|c|c|c|c|c|c|c|c|c|c|c|}
\hline Position & Jan & $F e b$ & Mar & $A p r$ & May & June & July & Aug & Sept & $O c t$ & Nov & Dec \\
\hline \multicolumn{13}{|l|}{ Geladandong } \\
\hline Mean TAG & -18.5 & -17.0 & -13.1 & -7.7 & -4.1 & 0.6 & 2.8 & 2.5 & -0.4 & -8.2 & -15.3 & -18.1 \\
\hline Mean ELA & -19.4 & -18.7 & -15.1 & -10.0 & -6.7 & -2.0 & 0.3 & 0.0 & -2.7 & -10.2 & -16.5 & 18.7 \\
\hline \multicolumn{13}{|c|}{ Mid-Tanggula } \\
\hline Mean TAG & -15.5 & -13.7 & -10.1 & -5.3 & -1.2 & 2.8 & 4.4 & 3.7 & 1.4 & -4.9 & -11.0 & -14.4 \\
\hline Mean ELA & -15.9 & -14.6 & -11.3 & -6.7 & -2.8 & 1.2 & 2.9 & 2.2 & 0.1 & -6.1 & -11.7 & -14.7 \\
\hline \multicolumn{13}{|l|}{ Bujarkyagri } \\
\hline Mean TAG & -9.9 & -8.2 & -5.5 & -1.3 & 1.9 & 5.0 & 7.1 & 6.4 & 4.5 & -0.8 & -5.4 & -8.3 \\
\hline Mean ELA & -10.9 & -10.5 & -8.6 & -4.7 & -2.0 & 1.0 & 3.3 & 2.5 & 1.2 & -4.0 & -7.2 & -9.0 \\
\hline
\end{tabular}

\footnotetext{
* Air temperature is not corrected for presence of the glaciers.
} 
Ding Yongjian and others: Climatology of Tanggula mountains

Table 4. Air temperature, in ${ }^{\circ} \mathrm{C}$, at ELA in various glacier systems of China (Shi and others, 1988)

Polar-continental glaciers $\quad$ Sub-continental glaciers $\quad$ Transitional glaciers $\quad$ Maritime glaciers

\begin{tabular}{lrrrrrrrrrrrr} 
No. & 1 & 2 & 3 & 4 & 5 & 6 & 7 & 8 & 9 & 10 & 11 & 12 \\
\hline Tso & -1.3 & -0.6 & -0.4 & 1.2 & 1.2 & 1.7 & 2.5 & 2.6 & 2.8 & 3.4 & 4.1 & 4.3 \\
Tao & -12.6 & -12.3 & -11.0 & -9.3 & -9.0 & -7.8 & -6.8 & -5.0 & -4.5 & -4.2 & -2.7 & -2.8 \\
\hline
\end{tabular}

1: No. 12 Glacier, Laohugou, Qilian mountains; 2: No. 5 Glacier, Yanglong River, Qilian mountains; 3: "July 1st" Glacier, Qilian mountains; 4: West Qongterang Glacier, Tien Shan mountains; 5: Hanas Glacier, Altay mountains; 6: No. 4 Glacier, Shuiguan River, Qilian mountains; 7: Buraldu Glacier, Karakoram mountains; 8: Batura Glacier, Karakoram mountains (in Pakistan); 9: No. 6 Glacier, Yulongshan, Hengduan mountains; 10: No. 3 Glacier, Guxiang, Nyainquentanglha mountains; 11: Alza Glacier, Nyaiquentanglha mountains; 12: Ruoguo Glacier, Nyaiquentanglha mountains (see Figure 1).

northeastwards from northern India along a corridor between Zhong and Tingri (Fig. 1) to converge between Baingion and Amdo (Fig. 2) (Qan and Chen, 1984). The other is the southeast path, through which humid air from the Bay of Bengal and the South China Sea is transported by south-easterly or southerly winds through the valleys of the Nujiang, Lancang and Yangtze Rivers, or along the gorges cutting through the Himalaya mountains, to reach the southwestern part of Qinghai Province (Cheng, 1984) (Fig. 1). According to wind data recorded aloft along the south side of the Tanggula mountains there is an obvious difference in the wind frequency in January and July (Fig. 3). The south and southeasterly winds are predominant during the monsoon period in summer on the south side of the Tanggula mountains. However, on the north side easterly winds are predominant in summer. It can be inferred that water vapour on the north side probably comes from the east during summer. Humid air can be transported to the glacierized areas of the north side along the eastern valleys.

The total area of glaciers on each side of the Tanggula mountains is about $2080 \mathrm{~km}^{2}$, of which $53 \%$ is on the north side and $47 \%$ on the south side. Therefore, the easterly path must be equally as effective as the southern one. This is also indicated by precipitation at lower altitudes, measured at weather stations on both sides of the range.

\section{PREGIPITATION IN THE GLACIER AREA}

Because it is affected by the plateau summer monsoon, summer precipitation predominates on both sides of the Tanggula mountains (Fig. 4). Precipitation between June and August is about $70 \%$ of the annual precipitation. The highest precipitation rate occurs in July. Precipitation in the east is larger than in the west. On the south side, for example, annual precipitation at Sogxian Station (Fig. 2) is $572.6 \mathrm{~mm}$, but at Nagqu it is about $400 \mathrm{~mm}$. In the north side of the mountains, annual precipitation at Zadoi Station is about $510 \mathrm{~mm}$, but at Tuotuohe it is

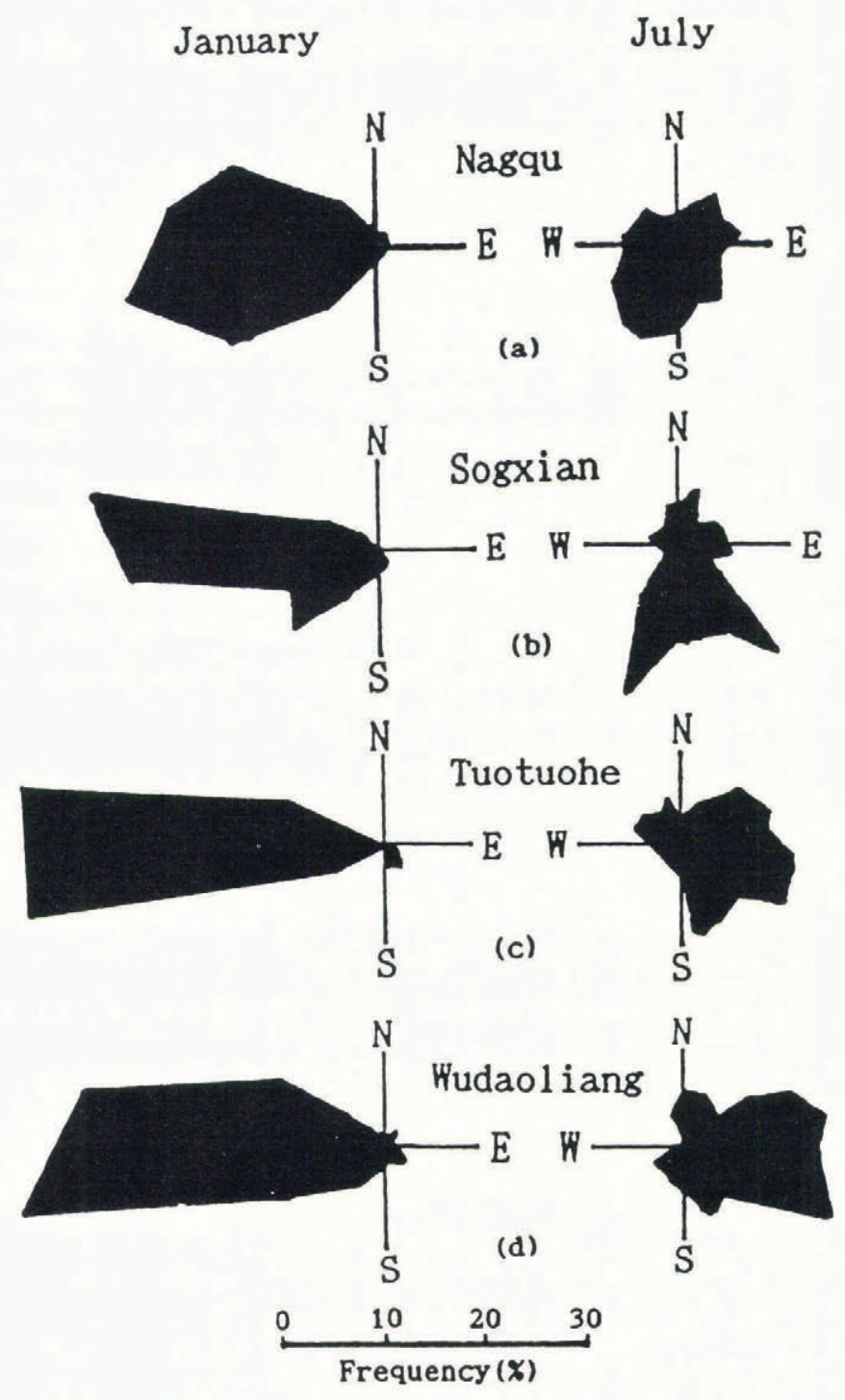

Fig. 3. Relative frequency of wind directions at $5000 \mathrm{~m}$ a.s.l. on both sides of the Tanggula mountains (1960-80). (a) and (b), south side; (c) and (d), north side. 


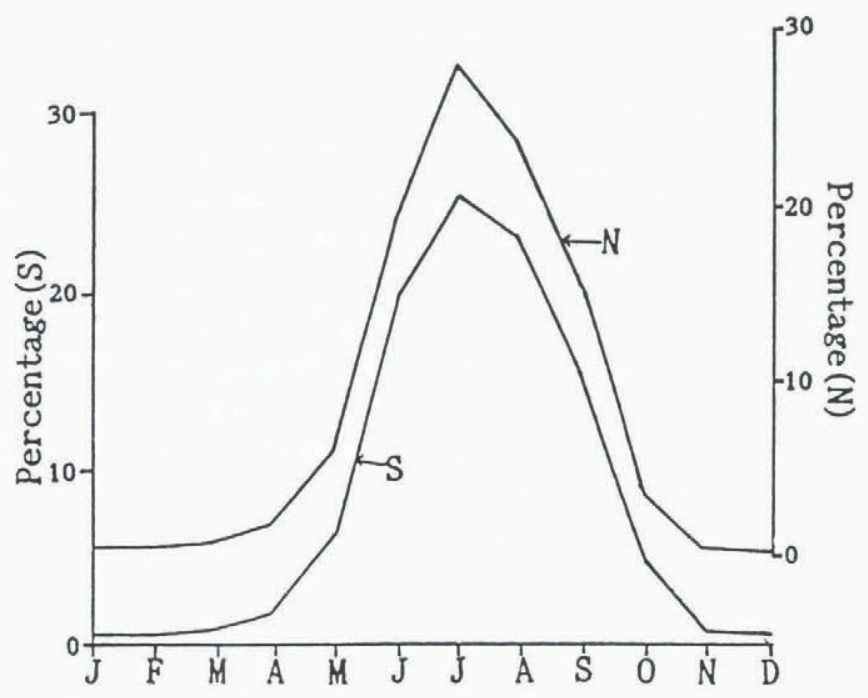

Fig. 4. Temporal distribution of precipitation on the south $(S)$ and north $(\mathcal{N})$ sides of the Tanggula mountains. (Average of Amdo, Nagqu and Sogxian Stations on the south side. Average of Yanshiping, Tuotuohe and Zadoi Stations on the north side. Note the shift in vertical axes.)

about $280 \mathrm{~mm}$. These differences in precipitation reflect the water vapour transport paths.

In general, precipitation tends to decrease towards the interior of the continent. However, it tends to increase with altitude near the alpine region of the plateau. For example, on the south side of the Tanggula mountains annual precipitation at Nagqu Station ( $4507 \mathrm{~m}$ a.s.l.) is $406.9 \mathrm{~mm}$, but at Amdo ( $4800 \mathrm{~m}$ a.s.l.) it is $441.6 \mathrm{~mm}$. On the north side of the mountains, at Yanshiping Station $(4720 \mathrm{~m}$ a.s.l.), it is $100 \mathrm{~mm}$ more than at Tuotuohe ( $4533 \mathrm{~m}$ a.s.l.). In 1989 , the measured precipitation at the terminal altitude of the Kangkyagquba Glacier, about $5250 \mathrm{~m}$ a.s.l., from 12 to 31 August, was $75.2 \mathrm{~mm}$, but at Tuotuohe Station during the corresponding period it was only $27.9 \mathrm{~mm}$. The annual accumulation in the firn area of Kangkyagquba Glacier at about $5950 \mathrm{~m}$ a.s.l. was $470 \mathrm{~mm}$ in $1987 / 88$ and $604 \mathrm{~mm}$ in $1988 / 89$, as measured in snow pits. In contrast, precipitation was only $198.5 \mathrm{~mm}$ $(1987 / 88)$ and $326.9 \mathrm{~mm}(1988 / 89)$ at Tuotuohe Station during the corresponding accumulation periods. These results indicate that precpitation in the glacier areas is higher than in the surrounding lowlands. Using the following empirical equation between the annual precipitation $(P e ; \mathrm{mm})$ and the mean annual air temperature $\left(T_{\text {aoo }}{ }^{\circ} \mathrm{C}\right)$ at the ELA in China $\left(-13^{\circ} \mathrm{C}<T_{\text {ao }}<2.5^{\circ} \mathrm{C}\right.$; correlation coefficient is 0.95 ) (Shi and others, 1988).

$$
\tau_{\text {ao }}=-42.8+\ln P e .
$$

The estimated annual precipitation at the ELA in the Geladandong area is between 430 and $640 \mathrm{~mm}$. If Tao averages $-11.0^{\circ} \mathrm{C}$, the mean annual precipitation at the ELA in the Geladandong region is approximately $520 \mathrm{~mm}$. This still reflects a dry climate in the glacier area.

In addition we have to point out that local convective precipitation is frequent, especially in the firn area where showers occurred every afternoon during the field period in 1989. Observations at the terminus of Kangkyagquba Glacier from 10 August to 1 September 1989 showed that convective precipitation occurred on 12 days, with a total amount of $23.9 \mathrm{~mm}$, which is $63.2 \%$ of the total number of days with precipitation, and $30.9 \%$ of the total amount of precipitation. Precipitation from synoptic-scale weather systems accounted for $69.1 \%$ of the total amount. It follows that convective precipitation cannot be ignored. Because air temperature decreases with altitude and precipitation increases with altitude, the distribution of the glaciers is closely associated with high-altitude areas. The largest glaciers all developed in the regions where the mountain peaks are more than $6000 \mathrm{~m}$ a.s.l. There are 50 peaks higher than $6000 \mathrm{~m}$ a.s.l. in the Geladandong region, and the unique ice cap and the largest valley glaciers in the Tanggula mountains are located there. The area of the glaciers in the west Tangggula mountains comprises $49.7 \%$ of the total glacierized area in the range. Another centre of present glacierization lies in the Bujarkyagri region of the east Tanggula mountains, where there are 16 mountain peaks over $6000 \mathrm{~m}$ a.s.l. within $20 \mathrm{~km}$ of each other. Large valley glaciers such as the Xuehui and Bugyai Glaciers are in this region. In the middle Tanggula mountains, where there are few peaks of more than $6000 \mathrm{~m}$ a.s.l., large valley glaciers are scarce although $42.9 \%$ of the total number of glaciers in the range lie in this area. The above relations between the distribution of glaciers and altitude also illustrate the influence of air temperature and precipitation on the development of glaciers. In the Geladandong area of the plateau interior, development of the present glaciers, which are found at very high altitude, depends on low air temperature and sufficient precipitation. In other areas of the range, glaciers can form at lower altitude because of higher precipitation.

Many glaciers in the Tanggula mountains are presently retreating. For example, the terminus of Kangkyagquba Glacier has retreated $520 \mathrm{~m}$ since 1969 (based on an aerial photograph in 1969 and a field survey in 1989), a mean retreat rate of $26 \mathrm{~m} \mathrm{a}^{-1}$. The estimated mean mass balance of Kangkyagquba Glacier is approximately $-160 \mathrm{~mm}$ from the $1950 \mathrm{~s}$ to the present (Ding and Xie, 1991). Evidence for retreat of glaciers in the north end of the Geladandong area were also found during an expedition in 1976 (Zhang, 1981). The mass budget for most glaciers appears to be negative.

\section{CONCLUSIONS}

Air temperature decreases northwestwards and with altitude. Moisture is carried to the Tangggula mountains along three principal paths. Precipitation decreases toward the interior of the plateau. However, precipitation tends to increase with altitude in the glaciated areas. Mean annual and summer air temperatures at the ELA are -12 to $-10^{\circ} \mathrm{C}$ and -1.0 to $1.0^{\circ} \mathrm{C}$, respectively. Annual accumulation in the firn area is about $500 \mathrm{~mm}$. The glaciers are polar-continental type, reflecting a dry and cold climate. Most of the glaciers are retreating and appear to have negative mass budgets under present climatic conditions. 


\section{REFERENCES}

Bai Zhongyuan. 1989. A study of relationship between climate and mountain glaciers. F. Glaciol. Geocryol., 11(4), 287-297. [In Chinese with English abstract.]

Cheng, C.X. 1984. An analysis of precipitation in Qinhai-Xizhang Plateau during May to August, 1979. In Symposium on Experiment of Meteorological Science in Qinhai-Xizhang Plateau. Vol. I. Beijing, Science Press, 279-288.

Ding Yongiian and Xie Zichu. 1991. A simple method of estimating mass balance of glacier. J. Glaciol. Geocryol., 13(3), 250-254. [In Chinese with English abstract.]

Kotlyakov, V. M. and A. N. Krenke. 1982. Investigations of the hydrological conditions of alpine regions by glaciological methods. International Association of Hydrological Sciences Publication 138 (General Assembly at Exeter 1982 - Hydrological Aspects of Alpine and High-Mountain Areas), 31-42.
Li Jijun and Zheng Benxing. 1986. The glaciers of Tibet. Beijing, Science Press.

Qan, Z. A. and F. M. Chen. 1984. An analysis of nascent vortex during pluvial period in the west of the plateau. In Symposium on Experiment of Meteorological Science in Qinhai-Xizhang Plateau. Vol. I. Beijing, Science Press, 229-242.

Shi Yafeng, Haung Maohuan and Ren Binghui. 1988. An introduction to the glaciers in China. Beijing, Science Press.

Zhang Linyuan. 1981. Glaciers at the source region of Tuotuo River in the upper reaches of the Changjiang and their evolution. F. Glaciol. Cryopedol., 3(1), 1-9. [In Chinese with English abstract.]

The accuracy of references in the text and in this list is the responsibility of the author/s, to whom queries should be addressed. 